\title{
ANALISIS HIGHER ORDER THINKING SKILLS (HOTS) CALON GURU MATEMATIKA DITINJAU DARI GAYA BELAJAR
}

\author{
Maimunah $^{1}$, Finata Rastic Andrari ${ }^{2}$, Nurmala Dewi Qadarsih ${ }^{3}$ \\ Universitas Indraprasta PGRI ${ }^{123}$ \\ Email: queenahakim@gmail.com ${ }^{3}$
}

\begin{abstract}
Abstrak
Upaya peningkatan kemampuan berpikir tingkat tinggi sejalan dengan tujuan Kemendikbud dalam penyempurnaan kurikulum yang tertuang dalam kurikulum 2013. Pada pelaksanaannya mengharuskan guru untuk mengetahui sejauh mana hasil pembelajaran yang telah dilakukan selama ini. Penilaian keberhasilan dalam pembelajaran tersebut dapat dilihat dari kemampuan berpikir tingkat tinggi (HOTS) siswa. Evaluasi juga harus dilakukan pada gaya belajar siswa yang beragam. Dengan mengetahui gaya belajar siswa, guru dapat menyiapkan lingkungan belajar yang mendukung dan memudahkan siswa menyerap informasi secara maksimal. Penelitian ini bertujuan untuk mendeskripsikan kemampuan berpikir tinggi mahasiswa calon guru matematika ditinjau dari gaya belajar. Jenis penelitian yang digunakan adalah penelitian deskriptif dengan pendekatan kualitatif dengan subjek penelitian sebanyak 6 orang mahasiswa Universitas Indraprasta PGRI semester V yang terdiri dari subjek bergaya belajar visual, auditori dan kinestetik yang masing-masing diwakili oleh 2 orang. Teknik analiis data yang digunakan adalah reduksi data, kategorisasi, sintesisasi, dan penyusunan hipotesis kerja.Hasil penelitian menunjukkan bahwa Subjek bergaya belajar visual mampu memenuhi kemampuanmenganalisis $100 \%$, aspek mengevaluasi $87,5 \%$ dan aspek mengkreasi $37,5 \%$. Subjek bergaya belajar auditori mampu memenuhi aspek menganalisis $87,5 \%$, aspek mengevaluasi $87,5 \%$ dan aspek mengkreasi $25 \%$. Subjek bergaya belajar kinestetik mampu memenuhi aspek menganalisis $100 \%$, aspek mengevaluasi $12,5 \%$ dan pada aspek mengkreasi $25 \%$.
\end{abstract}

Kata kunci: HOTS, calon guru, gaya belajar.

\begin{abstract}
The efforts to improve the ability to think at a higher level are in line with the goals of Kemendikbud in improving the curriculum set forth in the 2013 curriculum. The implemenation requires teachers to know the results of learning that has been done. The success in learning can be seen from Higher Order Thinking Skills (HOTS) of the students. In addition, the evaluation should also be carried out on the diverse learning styles of students. By knowing learning styles of students, teachers can prepare learning environments that support and facilitate students to absorb information maximally. This research aims to describe the higher order thinking skills of prospective mathematics teacher in terms of learning styles. This type of research was a descriptive study with a qualitative approach with research subjects were 6 students of Indrapasrta University PGRI Semester V consisting of subjects with visual, auditory and kinesthetic learning style subjects, where each subject was represented by 2 students. Data analysis techniques used were data reduction, categorization, synthesis, and preparation of working hypotheses. The results showed that visual learning style subjects were able to meet the ability to analyze by $100 \%$, evaluating aspects was $87.5 \%$ and creative aspects was $37.5 \%$. Auditory learning style subjects were able to fulfill the aspects of analyzing by $87.5 \%$, evaluating aspects by $87.5 \%$ and creative aspects by $25 \%$. Kinesthetic learning style subjects were able to fulfill the analysis aspects by $100 \%$, evaluating aspects by $12.5 \%$ and the creative aspects by $25 \%$.
\end{abstract}

Keywords: HOTS, prospective teachers, learning styles.

\section{PENDAHULUAN}

Matematika adalah salah satu ilmu yang berperan penting dalam perkembangan ilmu pengetahuan, teknologi, dan kemajuan daya pikir manusia. Pelajaran matematika diberikan mulai dari tingkat pendidikan dasar sampai kepada tingkat pendidikan tinggi sebagai bekal agar siswa memiliki kemampuan berpikir logis, analitis, sistematis, kritis, kreatif dan memiliki 
kemampuan bekerja sama yang baik. Pelajaran dan permasalahan matematika yang diberikan bertujuan untuk melatih kemampuan berpikir dan mengetahui posisi tingkat berpikir karena pemecahan masalah matematika sangat dipengaruhi oleh tingkat kemampuan berpikir.

Mengacu pada hasil PISA[1], National Center for Educational Statistics mempublikasikan bahwa hampir semua kemampuan siswa Indonesia hanya menguasai materi pelajaran sampai level 4 saja, sementara negara lain telah banyak yang mencapai level 5 dan 6 . Mendikbud [2]memaparkan bahwa tingkat pemahaman, pendalaman dan penguasaan materi siswa di Indonesia masih sangat rendah jika dibandingkan dengan negara lain di wilayah benua Asia. Sebagian besar kemampuan yang dikuasai siswa Indonesia hanya mampu mengukur kemampuan siswa pada tingkat melakukan dengan rata-rata prosentase $5 \%$. Artinya, proses pembelajaran yang selama ini dilakukan belum mampu menggali kemampuan berpikir tingkat tinggi yang meliputi memberikan alasan dengan informasi yang lengkap, mengelola informasi, membuat generalisasi, dan menyajikan data. Rendahnya kemampuan berpikir tingkat tinggi ini kemudian memicu adanya penyempurnaan kurikulum KTSP menjadi kurikulum 2013. Penyempurnaan kurikulum dari KTSP menjadi kurikulum 2013 antara lain pada standar isi dan standar penilaian. Pada standar penilaian [3] dilakukan adaptasi model-model penilaian standar internasional yang menitik beratkan pada kemampuan berpikir tingkat tinggi (HOTS).

Secara sederhana, kemampuan berpikir adalah kemampuan memproses informasi secara kognitif. Berdasarkan tingkatan proses, berpikir dibagi menjadi dua tingkat yaitu yaitu kemampuan berpikir tingkat rendah (lower order thinking skills) meliputi mengingat/C1, memahami/C-2 dan
menerapkan/C-3 dan kemampuan berpikir tingkat tinggi (higher order thinking skills) yang meliputi menganalisis/C-4, menilai/C5 dan mencipta/C-6)[4].

Kemampuan berpikir merupakan kemampuan memproses informasi secara mental atau kognitif, dimulai dari tingkat rendah hingga tingkat tinggi [5]. Kemampuan berpikir tingkat tinggi inilah yang menjadi sasaran pelaksanaan pembelajaran. Sehingga dalam pembelajaran guru harus mampu mengarahkan dan melatih siswanya agar memiliki kemampuan berpikir tingkat tinggi (HOTS). Selain, itu siswa juga harus dibiasakan memecahkan permasalahan yang membutuhkan pemikiran untuk menganalisis, mengevaluasi/ menilai dan mencipta. Terbiasanya siswa dengan permasalahan yang membutuhkan pemikiran/ yang mengukur HOTS tersebut membutuhkan peran penting dari guru. Peran penting ini menjadi tugas guru agar terbiasa menemukan, menyelesaikan dan menjelaskan permasalahan yang mengukur kemampuan berpikir tingkat tinggi. Kemampuan guru untuk menjelaskan penyelesaian permasalahan merupakan bagian dari kemampuan untuk menjelaskan materi secara luas dan mendalam, seperti diatur dalam peraturan pemerintah (PP) No. 19 tahun 2005, kemampuan menjelaskan materi ini disebut dengan kompetensi profesional. Tidak hanya kompetensi professional yang diperlukan seseorang untuk menjadi guru, tetapi ada kompetensi lain yang harus dimiliki oleh guru. Tuntutan lainnya adalah memberikan pembelajaran yang menantang, menyenangkan, memotivasi dan memberi ruang kepada siswa untuk dapat mengobservasi, bertanya, mencari tahu, dan merefleksi. Seorang guru yang memiliki kompetensi-kompetensi yang tercantum dalam peraturan pemerintah (PP) No. 19 tahun 2005 akan mendukung pencapaian siswa yang memiliki kemampuan berpikir tingkat tinggi. 
Penguasaan ketiga indikator kemampuan berpikir tingkat tinggi pada siswa yang terdiri dari menganalisis, menilai, dan mencipta sangat erat kaitannnya dengan gaya belajar yang dimiliki tiap siswa [5]. Menurut Dr. Rita dan Dr. Kenneth dalam [6] gaya belajar adalah suatu cara manusia mulai berkonsentrasi, memproses dan menampung informasi yang baru dan sulit. Menurut Widayanti [7], gaya belajar adalah suatu cara dalam menerima, mengolah, mengingat dan menerapkan informasi dengan mudah. Penunjang pencapaian hasil belajar adalah gaya belajar yang terbagi menjadi tiga yaitu visual, auditori, dan kinestetik [8]. Dengan demikian, dapat dikatakan bahwa gaya belajar adalah cara dari masing-masing individu menyerap informasi yang diperoleh baik dengan hanya melihat, mendengarkan informasi yang disampaikan atau bahkan dengan mencatat informasi yang disampaikan. Dikarenakan setiap siswa memiliki gaya belajar sendiri dalam belajar maka guru perlu memperhatikan gaya belajar yang dimiliki oleh siswa, karena hal ini dapat memberikan pertimbangan bagi guru dalam memilih metode pengajaran yang akan digunakan dalam menyampaikan materi untuk melatih kemampuan berpikir siswa menuju kemampuan berpikir tingkat tinggi (HOTS).

Berdasarkan latar belakang yang telah disampaikan sebelumnya, maka penting untuk meneliti kemampuan berpikir tingkat tinggi calon guru ditinjau dari gaya belajar sebagai bahan evaluasi bagi calon guru untuk mempersiapkan diri tehadap profesinya yang akan dating. Oleh karena itu, penelitian ini akan mendeskripsikan kemampuan berpikir tingkat tinggi (HOTS) calon guru matematika ditinjau dari gaya belajar.

\section{METODE}

Penelitian ini adalah penelitian deskriptif yang menggunakan pendekatan kualitatif. Penelitian deskriptif merupakan penelitian yang bertujuan mendeskripsikan kondisi secara objektif [9]. Sukmadinata dalam Kurniawan [9] menyatakan bahwa penelitian dengan data kuantitatif adalah penelitian dengan data bentuk gambar, kalimat, dan kata. Tujuan penelitian kualitatif adalah untuk menggambarkan dan mengungkapkan serta menjelaskan. Penelitian ini digunakan untuk mendeskripsikan kemampuan berpikir tingkat tinggi calon guru pada materi geometri bangun darat dan ruang yang ditinjau dari gaya belajar calon guru berdasarkan hasil pengerjaan calon guru pada soal yang mengukur hots, kuesioner gaya belajar, dan wawancara sebagai bentuk konfirmasi atas pengerjaan soal oleh calon guru.

Instrumen yang digunakan dalam penelitian adalahtes tertulis, kuesioner gaya belajar, dan wawancara. Soal tes tertulis yang digunakan dalam bentuk uraian bertujuan untuk mengetahui kemampuan berpikir tingkat tinggi subjek, Kuesioner gaya belajar dalam penelitian ini diambil dari buku[8], dan buku[10]. Lembar kuesioner gaya belajar diberikan kepada siswa sebelum penelitian dilaksanakan dengan terlebih dahulu diteliti kisi-kisi dan butir pernyataan gaya belajar visual, auditori, dan kinestetik (VAK), dan instrumen Wawancara mengggunakan pedoman wawancara yang digunakan untuk mengkonfirmasi hasil tes tertulis subjek yang kurang menyeluruh atau kurang bisa dipahami peneliti.

Aspek dan Indikator yang digunakan peneliti dalam menganalisis kemampuan berpikir tingkat tingg calon guru matematika ditinjau dari gaya belajar sesuai pendapat Kratwohl [11] yang menyatakan bahwa indikator yang mengukur kemampuan berpikir tingkat tinggi meliputi menganalisis, mengevaluasi, dan mengkreasi.Proses analisis data dalam penelitian kualitatif ini menggunakan tahapan yang dikemukakan oleh Moleong [12] yang meliputi reduksi data, 
kategorisasi, sintesisasi, dan penyusunan hipotesis kerja.

Menurut Sugiyono [13] mereduksi data berarti merangkum, memilih hal-hal yang pokok, memfokuskan pada hal-hal penting, mencari tema dan polanya, dan membuang yang tidak perlu. Reduksi data dalam penelitian ini, yaitu memfokuskan pada siswa yang memenuhi indikator dengan gaya belajar yang berbeda (visual, audiitori, kinestetik). Tahap kategorisasi dalam penelitian ini bertujuan untuk memilah setiap data yang memiliki kesamaan fokus permasalahan antara satu dengan yang lainnya. Kategorisasi juga masih menggunakan kode seperti halnya reduksi data yang kemudian dikenal dengan kategori. Setiap kategori diberi nama atau label

Pada tahap sintesisasi, dicari keterkaitan atau perpaduan antar kategori yang ditemukan. Hal ini bertujuan untuk memberikan label terhadap data-data tersebut. Proses sintesisasi pada penelitian mengamati keterkaitan antara kategori yang diperoleh dengan aspek-aspek pada tingkatan kemampuan berpikir tingkat tinggi (HOTS). Hipotesis kerja digunakan untuk menjawab rumusan masalah penelitian. Hipotesis kerja dalam penelitian ini dapat dilihat pada analisis dan pembahasan yang ada.

\section{HASIL DAN PEMBAHASAN}

Pengambilan data dilaksanakan pada bulan Desember 2019 dengan diawali kegiatan observasi kelas penelitian terlebih dahulu kemudian melakukan penyebaran kuesioner gaya belajar. Pada tahap observasi, peneliti mengamati bagaimana proses pembelajaran dan bagaimana subjek belajar. Dari hasil observasi, diketahui bahwa subjek adalah mahasiswa yang disiplin belajar, dan memiliki nilai ipk yang tergolong baik (hal ini berdasarkan nilai ipk yang didapatkan peneliti dari subjek penelitian).
Pada tahap penyebaran kuesioner gayar belajar, diperoleh data subjek yang terdiri dari 36 orang dengan rincian 6 laki-laki dan 30 perempuan. Berdasarkan hasil kuesioner, diketahui bahwa 8 orang bergaya belajar visual, 17 orang bergaya belajar auditori, dan 11 orang bergaya belajar kinestetik.

Selanjutnya dari keseluruhan jumlah subjek yaitu 36 orang, peneliti memfokuskan pada 6 subjek yang memiliki gaya belajar visual, auditori dan kinestetik yang masing-masing diwakili oleh 2 orang. Hal ini dilakukan karena jenis gaya belajar yang ada pada subjek lain nantinya akan terwakili oleh sampel subjek yang jenis gaya belajarnya ada pada diri mereka. Terkait dengan keenam subjek yang dijadikan dalam subjek penelitian ini, dapat dilihat pada Tabel 1 . Selain itu untuk menjaga identitas subjek dan mempermudah kegiatan analisis keenam subjek penelitian, dilakukan penginisialan nama dan pemberian kode subjek dalam penelitian.

Tabel 1.Hasil Kuesioner Gaya Belajar Calon Guru

\begin{tabular}{cccc}
\hline No & Inisial Siswa & Gaya Belajar & Kode \\
\hline 1 & NK & Visual & V1 \\
2 & AM & Visual & V2 \\
3 & ED & Auditori & A1 \\
4 & NF & Auditori & A2 \\
5 & AA & Kinestetik & K1 \\
6 & AD & Kinestetik & K2 \\
\hline
\end{tabular}

Setelah mengindentifikasi gaya belajar dan memilih subjek penelitian, peneliti memberikan tes kepada subjek penelitian kemudian dilanjutkan dengan wawancara subjek penelitian.

Hasil analisis kemapuan berpikir tingkat tinggi calon guru matematika ditinjau dari gaya belajar disajikan pada Tabel 2 . 
Tabel 2. Persentase Kemampuan Berpikir Tingkat Tinggi Calon Guru

\begin{tabular}{|c|c|c|c|c|c|c|c|}
\hline $\begin{array}{l}\text { Aspek } \\
\text { HOTS }\end{array}$ & Indikator & $\begin{array}{l}\text { V } \\
1\end{array}$ & $\begin{array}{l}\text { V } \\
2\end{array}$ & $\begin{array}{l}\mathbf{A} \\
\mathbf{1}\end{array}$ & $\begin{array}{c}\mathbf{A} \\
\mathbf{2}\end{array}$ & $\begin{array}{l}K \\
1\end{array}$ & $\begin{array}{l}\mathbf{K} \\
\mathbf{2}\end{array}$ \\
\hline \multirow{7}{*}{1} & Memberikan & $\sqrt{ }$ & $\sqrt{ }$ & $\sqrt{ }$ & $\sqrt{ }$ & $\sqrt{ }$ & $\sqrt{ }$ \\
\hline & Atribut & & & & & & \\
\hline & Mengorganisasikan & $\sqrt{ }$ & $\sqrt{ }$ & $\sqrt{ }$ & - & $\sqrt{ }$ & - \\
\hline & Mengintegrasikan & $\sqrt{ }$ & $\sqrt{ }$ & $\sqrt{ }$ & $\sqrt{ }$ & $\sqrt{ }$ & $\sqrt{ }$ \\
\hline & Mensahihkan & $\sqrt{ }$ & $\sqrt{ }$ & $\sqrt{ }$ & $\sqrt{ }$ & $\sqrt{ }$ & $\sqrt{ }$ \\
\hline & Jumlah & 4 & 4 & 4 & 3 & 4 & 3 \\
\hline & Rata-rata total & \multicolumn{2}{|c|}{$100 \%$} & \multicolumn{2}{|c|}{$87,5 \%$} & \multicolumn{2}{|c|}{$87,5 \%$} \\
\hline \multirow{7}{*}{2} & Mengecek & $\sqrt{ }$ & $\sqrt{ }$ & $\sqrt{ }$ & $\sqrt{ }$ & $\sqrt{ }$ & $\sqrt{ }$ \\
\hline & Mengkritisi & $\sqrt{ }$ & $\sqrt{ }$ & $\sqrt{ }$ & $\sqrt{ }$ & - & - \\
\hline & Mengajukan & $\sqrt{ }$ & $\sqrt{ }$ & $\sqrt{ }$ & $\sqrt{ }$ & $\sqrt{ }$ & - \\
\hline & hipotesis & & & & & & \\
\hline & $\begin{array}{l}\text { Melakukan } \\
\text { eksperimen }\end{array}$ & $\sqrt{ }$ & $\sqrt{ }$ & $\sqrt{ }$ & $\sqrt{ }$ & - & - \\
\hline & Jumlah & 4 & 4 & 4 & 4 & 2 & 1 \\
\hline & Rata-rata total & \multicolumn{2}{|c|}{$100 \%$} & \multicolumn{2}{|c|}{$100 \%$} & \multicolumn{2}{|c|}{$37,5 \%$} \\
\hline \multirow{6}{*}{3} & Menggeneralisasi & $\sqrt{ }$ & $\sqrt{ }$ & $\sqrt{ }$ & $\sqrt{ }$ & $\sqrt{ }$ & $\sqrt{ }$ \\
\hline & Merancang & $\sqrt{ }$ & - & - & - & - & - \\
\hline & Memproduksi & - & - & - & - & - & - \\
\hline & $\begin{array}{l}\text { Merancang } \\
\text { kembali }\end{array}$ & - & - & - & - & - & - \\
\hline & Jumlah & 2 & 1 & 1 & 1 & 1 & 1 \\
\hline & Rata-rata total & \multicolumn{2}{|c|}{$37,5 \%$} & \multicolumn{2}{|c|}{$25 \%$} & \multicolumn{2}{|c|}{$25 \%$} \\
\hline
\end{tabular}

Pada tabel 2, diperoleh bahwa subjek bergaya belajar visual (V1 dan V2) mampu memenuhi semua aspek dari kemampuan menganalisis yaitu sebesar 100\%. Pada aspek mengevaluasi, V1 dan V2 mampu memenuhi semua aspek dari kemampuan mengevaluasi (100\%). Sedangkan pada aspek mengkreasi memperoleh memiliki rerata total terendah yaitu sebesar $37,5 \%$ dengan tiap mahasiswa hanya mampu memenuhi sebesar 50\% dan $25 \%$ dari semua aspek mengkreasi. Keseluruhan data tersebut, menunjukkan bahwa subjek bergaya belajar visual cukup mampu memeriksa dan mengurai informasi yang masuk dan membagi-bagi atau menstrukturkan informasi ke dalam bagian yang lebih sederhana untuk mengenali pola atau hubungan, serta memformulasikan masalah. Hal ini dilandasi oleh kemampuan subjek dalam berpikir menggunakan gambar-gambar di otak mereka dan belajar belajar lebih cepat menggunakan tampilantampilan visual seperti gambar, diagram, tabel dan lainnya.
Pada aspek mengevaluasi subjek bergaya belajar visual mampu memahami perintah pada permasalahan yang diberikan dengan baik meskipun salah satu diantara subjek tidak melakukan pengecekan pada permasalahan yang diberikan, dapat dikatakan bahwa subjek bergaya belajar vsual cukup mampu menilai, menyangkal ataupun mendukung suatu gagasan dan memberikan alasan yang mampu memperkuat jawaban yang diperoleh, merumuskan hipotesis, mengkritik, dan melakukan pengujian hipotesis. Kemampuan mengevaluasi dapat dilakukan apabila subjek menganalisis informasi dengan tepat, memahami maksud peertanyaan, serta memberikan alasan/bukti yang akurat.

Pada aspek mengkreasi didapatkan bahwa V1 dan V2 mengalami kesulitan dalam memahami permasalahan yang diberikan. Rendahnya kemampuan mengkreasi ini disebabkan karena mengkreasi adalah level tertinggi dalam kemampuan berpikir tingkat tinggi. Selain itu, pada permasalahan yang diberikan, tidak diberikan petunjuk tampilan visual berupa gambar apapun, hal ini menyebabkan subjek bergaya belajar visual mengalami kesulitan dalam menganalisis dan mengevaluasi permasalahan tersebut.

Rerata total kemampuan berpikir tingkat tinggi subjek gaya belajar auditori (A1 dan A2) pada aspek menganalisis adalah $87,5 \%$ dengan masing-masing subjek mampu memenuhi aspek kemampuan menganalisis sebesar 100\% dan 75\%. Pada aspek mengevaluasi diperoleh rerata sebesar $100 \%$. Aspek mengkreasi untuk subjek bergaya belajar auditori memiliki nilai rerata terendah yaitu sebesar 25\%. Nilai ini lebih rendah jika dibandingkan dengan nilai kemampuan mengkreasi pada subyek bergaya belajar visual. Data tersebut menujukkan bahwa subjek bergaya belajar auditori mampu mengungkapkan apa yang diketahui dan ditanyakan, mampu 
membandingkan, serta mampu mengungkapkan dengan detail mengenai kesimpulan yang didapatkan dari permasalahan yang diberikan. Subjek bergaya belajar auditori (A1 dan A2) juga mampu mengintegrasikan penggunaan rumus pada permasalahan yang diberikan. Selain itu, A1 dan A2 mampu memaknai konsep pada permasalahan yang diberikan dengan baik. Meskipun salah satu subjek tidak menuliskan penyelesaian soal (A2) yang diberikan, namun pada saat wawancara subjek bergaya belajar auditori mampu menyatakan apa saja yang diketahui dan ditanyakan pada permasalahan yang diberikan. DePorter [14] berpendapat bahwa salah satu ciri gaya belajar auditori adalah merasa kesulitan dalam menulis, tetapi hebat dalam bercerita atau lebih pandai dalam mengeja lebih keras daripada menuliskannya. Sehingga subyek (A2) juga melakukan hal demikian, yakni tidak menuliskan apa yang diketahui dan ditanyakan pada soal, namun mereka paham dan mampu mengungkapkan apa yang diketahui tersebut.

Penguasaan aspek menganalisis ini menunjukkan bahwa A1 dan A2 memiliki tingkat kemampuan menganalisis yang cukup baik. Mahasiswa cukup mampu memeriksa dan menguraikan informasi yang didapatkan kemudian membaginya kedalam bagian yang lebih sederhana untuk mengenali pola atau hubungan, serta memformulasikan masalah. Nilai kemampuan menganalisis ini masih lebih rendah sedikit jika dibandingkan dengan nilai pada subyek bergaya belajar visual. Ini dipengaruhi oleh kelemahan mahasiswa bergaya belajar auditori yaitu lemah dalam aktivitas visual. Artinya informasi tertulis kadang sulit diterima oleh mahasiswa bergaya beajar auditori.

Pada aspek mengevaluasi, didapatkan bahwa subjek bergaya belajar auditori (A1 dan A2) juga cukup mampu menilai, menyangkal ataupun mendukung suatu gagasan dan memberikan alasan yang mampu memperkuat jawaban yang diperoleh, merumuskan hipotesis, mengkritik, dan melakukan pengujian hipotesis yang diberikan. Sedangkan pada aspek mengkreasi memiliki nilai rerata terendah yaitu sebesar $25 \%$. Nilai ini lebih rendah jika dibandingkan dengan nilai kemampuan mengkreasi pada mahasiswa bergaya belajar visual. Hal ini disebabkan oleh kemampuan mengevaluasi permasalahan yang kurang cukup baik.

Pada subjek bergaya belajar kinestetik (K1 dan K2) mampu memenuhi aspek menganalisis sebesar $87,5 \%$ dengan tiap subyek mampu memenuhi sebesar $100 \%$ dan $75 \%$. Pada aspek mengevaluasi subjek bergaya belajar kinestetik diperoleh rata-rata sebesar 37,5\%, sedangkan pada aspek mengkreasi diperoleh rata-rata sebesar $25 \%$. Data tersebut menunjukkan bahwa subyek bergaya belajar kinestetik (K1 dan K2) memiliki tingkat kemampuan menganalisis yang cukup baik. Subyek cukup mampu memeriksa dan menguraikan informasi yang didapatkan kemudian membaginya kedalam bagian yang lebih sederhana untuk mengenali pola atau hubungan, serta memformulasikan masalah.kemampuan menganalisis tersebut diwujudkan dalam penulisan rumus, penggunaan rumus terhadap permasalahan yang diberikan, dan pemaknaan konsep yang baik. Hal ini terjadi karena ketika seseorang memikirkan sesuatu berarti ia mengarahkan diri pada objek tertentu, menyadari kehadirannya seraya secara aktif menghadirkannya dalam pikiran dan mempunyai gagasan atau wawasan tentang objek tersebut [15]. Kemampuan menganalisis subjek bergaya belajar kinestetik dilandasi salah satunya oleh kemmapuan dalam belajar melalui manipulasi dan praktik, pnggalian informasi melalui menggaris bawahi point-point yang dibaca agar informasi yang dianalisis lebih cepat dipahami. 
Aspek mengevaluasi didapatkan rata-rata sebesar $12,5 \%$. Nilai ini lebih rendah jika dibandingkan dengan aspek mengevaluasi pada subyek bergaya belajar visual dan auditori. Hal ini menunjukkan bahwa subyek bergaya belajar kinestetik kurang mampu menilai, menyangkal ataupun mendukung suatu gagasan dan memberikan alasan yang mampu memperkuat jawaban yang diperoleh, merumuskan hipotesis, mengkritik, dan melakukan pengujian hipotesis yang diberikan. Kemampuan mengevaluasi dapat dilakukan apabila subyek bergaya belajar mampu menganalisis informasi dengan tepat, memahami maksud pertanyaan dengan benar, serta memberikan alasan/bukti yang akurat. Namun karena adanya kelemahan subyek bergaya belajar kinestetik yaitu belajar dengan aktivitas fisik, maka dapat dipastikan bahwa mahasiswa bergaya belajar kinestetik akan kurang mampu mengevaluasi informasi tanpa aktivitas fisik yang berarti. Pada aspek mengkreasi, didapatkan bahwa bergaya belajar kinestetik memiliki kemampuan menggeneralisasi yang kurang, hal ini disebabkan karena rendahnya kemampuan mengevaluasi pada tingkatan sebelumnya.

Dengan adanya perbedaan nilai rata-rata subyek bergaya belajar visual, auditori dan kinestetik pada tabel 2, dapat dijadikan pertimbangan bagi guru dalam memilih strategi pengajaran yang akan digunakan dalam menyampaikan materi di kelas dengan menggunakan gaya belajar karena bahwasanya penerapan dari gaya belajar yang sesuai akan meningkatkan pembelajaran [16]. Hal tersebut sesuai dengan beberapa penelitian yang dilakukan oleh Gaiger terhadap beberapa mahasiswa dalam Widayanti [17] yang menunjukkan bahwa dengan gaya belajar yang mirip dosen pengampu mata kuliah tertentu, mahasiswa cenderung memiliki kinerja yang lebih baik atau lebih tinggi tingkat kepuasannya.

\section{KESIMPULAN}

Berdasarkan hasil penelitian dan pembahasan yang telah dilakukan, maka diperoleh kesimpulan sebagai berikut:

1. Subjek bergaya belajar visual mampu memenuhi kemampuan pada aspek menganalisis sebesar $100 \%$, pada aspek mengevaluasi sebesar $87,5 \%$ dan pada aspek mengkreasi sebesar $37,5 \%$

2. Subjek bergaya belajar auditori mampu memenuhi kemampuan ada aspek menganalisis sebesar $87,5 \%$, pada aspek mengevaluasi sebesar $87,5 \%$ dan pada aspek mengkreasi sebesar 25\%

3. Subjek bergaya belajar kinestetik mampu memenuhi kemampuan ada aspek menganalisis sebesar $100 \%$, pada aspek mengevaluasi sebesar $12,5 \%$ dan pada aspek mengkreasi sebesar $25 \%$

\section{DAFTAR PUSTAKA}

[1] OECD, "PISA 2012 Results in Focus : What 15-year-olds know and what they can do with what they know," 2012.

[2] Mendikbud, Konsep Pendekatan Saintifik. Jakarta: Kementrian Pendidikan dan Kebudayaan, Badan Pengembangan Sumber Daya Manusia Pendidikan dan Kebudayaan dan Penjamin Mutu, 2013.

[3] I. Widana, Modul Penyusunan Soal HOTS. Jakarta: Departemen Penddikan dan Kebudayaan, 2017.

[4] S. Sofiyah, Susanto, and Setiawan, "Pengembangan Paket Tes Kemampuan Berpikir Tingkat Tinggi Matematika Berdasarkan Revisi Taksonomi Bloom Pada Siswa Kelas V SD," J. Artik. Ilm. Mhs., vol. I (1), pp. 1-7, 2015.

[5] K. Purbaningrum, "Kemampuan Berpikir Tingkat Tinggi Siswa SMP dalam Pemecahan Masalah Matematika Ditinjau dari Gaya Belajar," $J$. Pendidik. Mat., vol. 10 (2), 2017.

[6] N. Subini, Rahasia Gaya Belajar Orang Besar. Yogyakarta: PT. Buku Kita, 2011.

[7] F. Widayanti, "Pengaruh 
Pengelompokkan Siswa Berdasarkan Gaya Belajar dan Multiple Intelligences pada Model Pembelajaran Learning Cycle terhadap Hasil Belajar Kimia Siswa Kelas XI IPA SMAN 3 Lumajang," Universitas Negeri Malang, 2010.

[8] D. Bobbi, R. Mark, and S.-N. Sarah, Quantum Teaching: Mempraktikkan Quantum Learning Di Ruang-ruang Kelas, 19th ed. Bandung: Kaifa, 2014.

[9] A. Kurniawan, Metodologi Penelitian Pendidikan. Cirebon: PT Remaja Rosdakarya, 2018.

[10]A. Gunawan, Genius Learning Strategy. Jakarta: PT Gramedia Pustaka Utama, 2012.

[11]L. Anderson and D. Krathwohl, Kerangka Pembelajaran, Pengajaran dan Assesemen. Yogyakarta: Pustaka Pelajar, 2015.

[12]L. Moleong, Metode Penelitian Kualitatif. Bandung: PT. Remaja Rosdakarya, 2009.

[13] Sugiyono, Metode Penelitian Kuantitatif, Kualitatif, dan $R \& D$. Bandung: Alfabeta, 2015.

[14]B. DePorter, M. Readon, and S. S. Nourie, Quantum Learning: Membiasakan Belajar nyaman dan menyenangkan. Bandung: Kaifa, 2015.

[15]U. Wardiana, Psikologi Umum. Editor P3M STAIN Tulungagung. Tulungagung: PT. Bina Ilmu, 2004.

[16]T. Tub'c and K. Hamilo glu, Linking Learning Style and Teaching Styles. Serbia: Faculty of Education, Unversity of Novi Sad, 2009.

[17]F. Widayanti, "Pentingnya Mengetahui Gaya Belajar Siswa dalam Kegiatan Pembelajaran di Kelas," J. Erud., vol. 2 (1), 2013. 